\title{
SHIELDING THOSE WHO HIGHLIGHT THE EMPEROR'S NEW CLOTHES - DOES THE CONSTITUTION DEMAND A JOURNALISTIC PRIVILEGE?
}

\author{
by Jonathan Swanepoel*
}

Met Prince Phillip at the home of the blues

Said he'd give me information if his name wasn't used

He wanted money up front, said he was abused

By dignity ${ }^{1}$

\section{Introduction}

In his judgment in the English case of $R \vee$ Derby $M C$, ex parte $B,^{2}$ the then Lord Chief Justice of England, Lord Taylor, stated that legal professional privilege was a 'fundamental condition on which the administration of democracy as a whole rests'. ${ }^{3}$ This privilege holds that a legal practitioner may not, without the leave of his client, answer any question addressed to him on the witness stand regarding information provided by the client. ${ }^{4}$ Thus, in the interests of justice, we allow (even force) a witness who may have crucial information on the matter at hand to refuse to provide such information.

Whilst on similar lines English law recognises a journalistic privilege, ${ }^{5}$ South African law recognises no journalistic privilege. ${ }^{6}$ This means that when a journalist is asked a question whilst on the witness stand, they must answer that question. This includes questions regarding journalistic sources. Failure to answer any such question is harshly penalised, including imprisonment for up to five years. 7

At the heart of the matter is this: Should a journalist ever be forced to reveal his or her sources in the preparation of an article?

BCom LLB (UP), candidate attorney, Webber Wentzel Bowens, Johannesburg.

Bob Dylan Dignity (1994).

1996 AC 487.

n 2 above, 507.

PJ Schwikkard 'Private Privilege', in PJ Schwikkard \& SE Van der Merwe (eds)

Principles of evidence (2002) 134. The statement above is obviously oversimplified in that various requirements must be met before the privilege can exist. These include that the information provided must have been made in confidence for the purposes of obtaining legal advice. Also interesting is in whom the privilege vests. The client and not the legal practitioner is the owner of the privilege, and only the client may waive it.

5 See eg X Ltd v Morgan Grampian (Publishers) Ltd 19902 WLR 1000.

$6 \quad S \vee$ Cornelissen, Cornelissen v Zeelie NO 19942 SACR 41 (W); Schwikkard (n 3 above) 141.

7 See eg sec 189 of the Criminal Procedure Act 51 of 1977. 
Journalists need sources to enable them to produce stories. The term 'off the record' is synonymous with journalism, and one must wonder how many people would provide journalists with information if there was a chance that their identity could or might be made public. Stated differently, how many more people would provide journalists with material if they knew that a journalist could not be compelled to reveal their identity?

In its current state, both South African criminal and civil law offer mechanisms designed to compel witnesses to answer questions posed to them by sanctioning a refusal to answer a question with detention. ${ }^{8}$ In the absence of a recognised journalistic privilege, journalists, if asked about their sources, must answer the question posed to them or risk being incarcerated. This clearly places journalists in a Catch22 type of situation: risk your career for revealing your sources or your liberty for not.

2

\section{Section 189 proceedings}

\section{Section 189(1) of the Criminal Procedure Act reads as follows:}

If any person present at criminal proceedings is required to give evidence at such proceedings and refuses to be sworn or to make an affirmation as a witness, or, having been sworn or having made an affirmation as a witness, refuses to answer any question put to him or refuses or fails to produce any book, paper or document required to be produced by him, the court may in a summary manner enquire into such refusal or failure and, unless the person so refusing or failing has a just excuse for his refusal or failure, sentence him to imprisonment for a period not exceeding two years or, where the criminal proceedings in question relate to an offence referred to in Part III of Schedule 2, to imprisonment for a period not exceeding five years.

Despite the rather clumsy formulation, the core - and sting - of section 189 are immediately apparent. At the heart of the section lies the notion that if a witness refuses to testify, he bears the onus of establishing that he had a just excuse not to. ${ }^{9}$ The constitutionality of this reversed onus will be addressed below. Clearly, a failure to provide the court with a just excuse will result in incarceration, for Act 51 of 1977.

9 That this formulation resulted in a reverse onus for the witness to discharge was confirmed by Ackerman J in S v Leepile 19903 SA 988 (W) 998B. In his judgment, Ackerman $\mathrm{J}$ held that the witness bears the onus of proving on a balance of probabilities that he has a just excuse. Interestingly, in reaching his conclusion, the learned judge rejected an argument by counsel that is perhaps more reflective of current jurisprudence when the impact of the Constitution is considered. According to counsel, sec 189 proceedings should work in such a way that where the witness concerned provides evidentiary material which could be considered a just excuse, the state must then prove beyond reasonable doubt the non-existence of such material (997I-J). 
up do to five years, should the crime for which the testimony is sought be of a particular nature. ${ }^{10}$

In addition to functioning in the broadest sense whenever a witness is on the stand, section 189 operates in tandem with section 205 of the Criminal Procedure Act. Section 205 allows for any person who 'is likely to give relevant and material information' about an alleged offence to be subpoenaed to appear before a judicial officer to testify under oath. ${ }^{11}$ Section $205(2)$ incorporates the provisions of section 189 mutatis mutandis, thus extending section 189 beyond the trial phase. The penal provisions that characterise section 189 are watered down in section 205. In terms of section 205(4), a judicial officer may only impose imprisonment if he believes that the information sought by the subpoena is 'necessary for the administration of justice or the maintenance of law and order'.

Thus, the essential question is: What may be considered a just excuse?

\section{Pre-constitutional case law}

\subsection{Kader}

Prior to the Supreme Court of Appeal decision in Attorney General, Transvaal $v$ Kader ${ }^{12}$ the position in South African law was that only a legal excuse could be considered to be a just excuse. In other words, only if a witness could claim some form of legal privilege or other legally recognised reason for not testifying, was it recognised as being a just excuse. ${ }^{13}$ In Kader, EM Grosskopf JA convincingly ended the uncertainty regarding the section. Whilst refusing to define all the circumstances which would give rise to a just excuse, the Court felt that to restrict the phrase to simply a legal excuse would be contrary to the intention of the legislature. ${ }^{14}$ In Kader, the Court recognised that where it was humanly intolerable for a witness to testify, that witness would have a just excuse. However, the Court was

The crimes listed in Part III of Schedule 2 of the Criminal Procedure Act are sedition, public violence, arson, murder, kidnapping, child-stealing, robbery, housebreaking, whether under the common law or a statutory provision, with intent to commit an offence, contravention of the provisions of secs 1 and $1 \mathrm{~A}$ of the Intimidation Act 72 of 1982, any conspiracy, incitement or attempt to commit any of the above-mentioned offences, and treason.

11 Sec 205(1)

12 Attorney-General, Transvaal v Kader 19914 SA 727 (A).

13 Prior to Kader, the Supreme Court of Appeal touched on the matter in $S V$ Weinburg 19664 SA 660 (A), where Steyn CJ was of the opinion that the term 'just excuse' contained in the Criminal Procedure Act 56 of 1955 could embrace more than simply a legal excuse, but that 'the excuse tendered would have to be of sufficient cogency ... for the witness to be absolved of the duty not to withhold the truth from the Court' (666A).

14 For criticism of this approach to statutory interpretation under the 1996 Constitution, see C Botha Statutory interpretation (2005). 
simultaneously mindful that there would be cases where a just excuse would be present, but it would not necessarily be humanely tolerable for the witness to testify, adding the rider to its judgment that it (the judgment) should not be treated as a legislative enactment.

\subsection{Cornelissen}

Directly relevant to the current discussion, the High Court in Cornelissen was faced with what, for a journalist acting in his professional capacity, would constitute a just excuse. ${ }^{15}$ The facts of the case, briefly, were that $C$ reported on a meeting where certain slogans were chanted by the main speaker, including 'Kill the farmer, kill the boer'. ${ }^{16}$ After publication of the article, the police opened a docket against the speaker, and subpoenaed the testimony of C. C refused to testify. He cited the fact that the press needed to be seen to have a relationship with their sources - to compromise this would damage his reputation and hamper his future ability to obtain news. These factors were rejected by the Court $a$ quo. $\mathrm{C}$ was sentenced to 12 months imprisonment.

The finding ${ }^{17}$ and the sentence were subsequently appealed in the High Court. On appeal and in response to argument by the appellant, ${ }^{18}$ the Court (per Schabort J) held that, with regard to the issuing of a subpoena to journalists the Court had to strike a balance amongst three factors. ${ }^{19}$ This test, and the three factors which need to be balanced, are only to be applied in determining whether or not to issue a subpoena, and not to determine whether or not a subpoenaed journalist has a just excuse not to testify.

The Court stressed again that no journalistic privilege exists. However, the Court found that, in casu, it was not a proven necessity for the appellant to testify and that the potential public advantage of his testimony was outweighed by the potential public prejudice thereof. Thus, at its crux, the Court's decision is a weighing up of public interest in the administration of justice and the public interest in allowing the press to act free from interference or threat of forced testimony.

15 S v Cornelissen; Cornelissen v Zeelie NO 19942 SACR 41 (W).

16 Considered to be hate speech by the South African Human Rights Commission: Freedom Front Plus v Human Rights Commission 200311 BCLR 1283.

17 The court a quo held that there was no just excuse.

18 The appellant argued that, in the current case, the issuing of a subpoena against him simply amounted to a failure by the police to exercise their role properly as all the information sought by the prosecution against the appellant could have been ascertained by a reasonable police investigation.

19 These were (1) freedom of the individual and in particular his right to retain information for himself, (2) the need for effective prosecution of crime which could result in witnesses to that crime being compelled to testify, and (3) the need for the press to be able to report freely and fairly but responsibly on newsworthy events. 
Both Kader and Cornelissen were decided prior to the enactment of both the interim ${ }^{20}$ and the final Constitutions. ${ }^{21}$ It is interesting that, although in a different context, section 189 was amongst the first to be placed under the lens of the Constitutional Court. In Nel $v$ Le Roux, the court was forced to address the constitutionality of section 189. 22 The challenge in Nel was based on a violation of the rights to freedom and security of the person and privacy, as well the rights to remain silent and to be presumed innocent. ${ }^{23}$ In the verdict of a unanimous court, Ackerman $\mathrm{J}$ chose not to deal with what would be deemed to be a just excuse in terms of the Constitution and states that it is not ... our task, but that of other courts ... to determine what this means although such determination have due regard for the objects of the Constitution' 24

It is submitted that this position is unsatisfactory. The closest that the court gets to finding any concrete principle is its holding that 'there is nothing in the provisions of section 205, read with section 189 of the Criminal Procedure Act, which compels or requires the examinee to answer a question (or for that matter to produce a document) which would unjustifiably infringe or threaten to infringe any of the examinee's Chapter 3 rights. ${ }^{25}$ This broad stroke is limited - an inquiry should then be made as to whether it is possible to save any such infringement by use of the limitation clause. ${ }^{26}$ The modus operandi proposed by the learned Judge is the following:

This is what the magistrate in the present case should have done in the first instance. If he had found that in answering any of the questions the examinee's chapter 3 rights would be infringed, he should have held that this constituted a 'just excuse' for the examinee's refusal to answer, unless of course he came to the conclusion in respect of any particular question that the section 189 compulsion to answer constituted, in the context of the section 205 enquiry, a limitation on the examinee's right which was justified under section 33(1) of the Constitution. If he had concluded that there entered into force on 27 April 1994.

21 Constitution of the Republic of South Africa 1996.

22 Nel $v$ le Roux 19963 SA 562 (CC). The actual section forming the challenge in Nel was sec 205 of the Criminal Procedure Act. As highlighted above, sec 189 is incorporated into sec 205. Thus the constitutionality of sec 189 was at stake in Nel.

23 n 21 above, para 4-5.

24 n 21 above, para 8. The objects of the Constitution are described in sec 1 of the Constitution.

25 n 21 above. Nel was decided under the interim Constitution, where the Bill of Rights was included in Chapter 3 as opposed to Chapter 2. 
was no such infringement nor any other just excuse for refusing to answer, he should have compelled the applicant to answer.

This means that a witness is not obliged to answer any question which would violate a fundamental right, unless there can be a reasonable or justifiable limitation of the right in the opinion of the judicial officer. This would at face value imply some form of shield, certainly. However, the onus requirement is still vague. The wording is that "unless of course he can come to the conclusion that the question was a reasonable limitation of the right'. Little is said about how this conclusion is to be reached - is it mero meto or must the party seeking the evidence establish such?

Even more worrying than this, though, is something which goes directly to the constitutionality of section 189. According to Ackerman J, a witness who refuses to testify is not an accused person for purposes of enjoying the rights afforded to accused persons. ${ }^{27}$ In terms of section $35(3)(f)$, every accused person has the right to be legally represented at proceedings. Section 35(2)(c) allows for detained persons to enjoy the same right. This creates a bizarre situation. If a witness refuses to answer a question, in terms of the natural reading of section 189 , an inquiry into whether that witness has a just excuse is then held. As the witness is not an accused person, the witness does not automatically have a right to be represented. However, if no just excuse is found, then the same person becomes a detained person entitled to legal counsel.

Further, even though a witness falling within the scope of section 189 is not entitled to 'fair trial' rights in terms of section 35(5), he or she is entitled to 'the interposition of an impartial entity, independent of the executive and the legislature to act as arbiter between the individual and the state'. ${ }^{28}$ This distinction drawn by the Court is perhaps both overly-fine and alarmingly broad. The Court's reasoning is unconvincing - because a recalcitrant witness is not formally charged with any crime and not actually convicted of an

27 Currently contained in sec 35(2) of the final Constitution; Nel (n 21 above) para 11.

$28 \mathrm{Nel}$ (n 21 above) para 14. These requirements are laid down by Ackerman J so as not to constitute detention without trial. What is interesting in the judgment is that the learned Judge refuses to equate a fair trial in terms of the rights of accused persons with a trial in the context of detention without one. To him, the latter is far less stringent. 
offence, they are not accused of anything. ${ }^{29}$ This is contrary to even the section headings in the Criminal Procedure Act which, for section 189 , refer to 'Recalcitrant Witnesses'. Thus, they are indeed accused of something - the contravention of a legal duty to testify.

The broadness of the court's approach is equally disquieting - a person may be deprived of their liberty provided that it is an impartial entity, independent of the executive and the legislature and able to act as an arbiter between individual and state. Whilst in Nel the court clearly envisages a judicial entity, it opens the door for a number of other entities which meet the requirements laid out in the judgment to detain people without a formal, criminal trial. ${ }^{30}$ What adds to this is that where such detention is ordered, it does not amount to a violation of the right to freedom and security of the person and hence no limitation analysis is allowed.

To return then to the question at hand - has the Constitutional Court opened the door for some form of journalistic privilege? From the pre-Nel case law it is clear that some form of expansive interpretation of section 189 should be allowed. What then is the impact of $\mathrm{Nel}$ on the status quo?

Ackerman J's opinion is that where a question infringes, or threatens to infringe, upon a fundamental right, the witness has a prima facie just excuse. In the context of journalists, compulsory disclosure of sources clearly poses problems to the right to privacy and to freedom of expression. It is to these areas that attention is now drawn.

This distinction in itself renders any reverse onus argument relating to sec 189 totally defective. The presumption of innocence is included in sec 35(3)(h) of the Constitution - the very body of rights that is excluded by the judgment in Nel. The same subsection includes the right to remain silent and the right of the accused not to testify. Thus, despite the Court's rejection of reverse onus clauses in cases such as S v Zuma 19951 SACR 568 (CC) (where sec 217(1)(b)(ii) of the Criminal Procedure Act was declared unconstitutional). Also in S v Coetzee 19973 SA 527 (CC), the Court declared unconstitutional a statutory provision that presupposed guilt unless a defence could be raised. This is exactly the situation imposed by sec 189. Finally, sec 189 does not impose a mere evidentiary burden - it imposes a legal burden which is problematic in terms of the Court's decision in Scagell $v$ Attorney-General of the Western Cape 19962 SACR 579 (CC). For a discussion of these and other cases, see PJ Schwikkard 'A constitutional perspective on statutory presumptions' in Schwikkard \& van der Merwe (n 3 above) 482-483.

$30 \mathrm{Eg}$, independent bodies such as ICASA theoretically act in exactly the capacity contemplated by the Court. 
The right to privacy is contained in section 14 of the Constitution and specifically includes 'the right not to have the privacy of [one's] communications infringed'. 31

As with a legal practitioner's privilege, an essential point to be determined is to whom such a privilege attaches. Is it to the journalist or is it to the source? The answer, perhaps surprisingly, appears to be both.

In Bernstein $v$ Bester, ${ }^{32}$ the Constitutional Court contemplated the question of a legitimate expectation of privacy. In terms of Ackerman J's judgment, such an expectation will exist when there is a subjective expectation of privacy which has been recognised by society as being objectively reasonable. ${ }^{33}$

In terms of the common law, a breach of privacy occurs where facts derived from a confidential relationship are disclosed. ${ }^{34}$ The relationship between a journalist and his sources is at heart strictly confidential. The words 'off the record' are denoted in the dictionary as meaning confidential. Thus, where a source provides information 'off the record', he has, at least in terms of the common law, an expectation of privacy which is breached by the subsequent disclosure of the information. Whilst, according to the Constitutional Court in Bernstein $v$ Bester, we should not automatically equate common law notions of privacy with its fundamental right relatives, ${ }^{35}$ it seems that such a determination must inform the notion of a subjective expectation of privacy on behalf of a source providing off the record information to a journalist.

This therefore goes to the reasonableness of the privacy reliance - is it reasonable for someone to expect to be afforded anonymity when giving information off the record? It is widely acknowledged that any interference with a journalist's ability to harvest information has a chilling effect on the media. ${ }^{36}$ Considering the importance of the role of the media as an agent of democracy, ${ }^{37}$ there is clearly tremendous importance that in an open and democratic society the media is able to operate 'unchilled', so to speak. This would then establish a right to privacy for the source, suggesting that, as for legal

\footnotetext{
Sec 14(d) of the Constitution.

Bernstein v Bester 19962 SA 751 (CC).

Bernstein (n para 31 above) 75.

J Neethling et al Law of delict (2001) 356.

Bernstein (n para 31 above) 71.

See eg the decision of the European Court of Human Rights in Goodwin v United Kingdom 200235 EHRR 18; G Price 'Pack your toothbrush: Journalists, confidential sources and contempt of court' (2003) 8 Media and Arts Law Review 259265. 
professional privilege, the privilege may vest not in the journalist but actually in the source. This in turn has far-reaching implications for a journalist - as for a lawyer who breaches privilege - both legally and ethically. 38

But at the same time, a journalist enjoys a specific right not to have the privacy of his communications infringed. ${ }^{39}$ Whilst there can be no doubt that much of the ambit of this section relates to electronic surveillance, ${ }^{40}$ by the same measure it is a very limited interpretation of the section that excludes non-surveillance infringements of such communications. Information relayed from one person to another clearly constitutes communication ${ }^{41}$ and to force the details (including the identity of the parties) of that conversation to be revealed destroys its privacy.

It is, therefore, apparent that in line with the formulation of section 189 proposed in $\mathrm{Nel}$, forcing a journalist to reveal sources constitutes a violation of the right to privacy.

\section{6}

\section{Freedom of expression}

In Freedom Front $v$ South African Human Rights Commission, ${ }^{42}$ a special committee of the South African Human Rights Commission held that the right to freedom of expression was, whilst not the preeminent right, fundamental to the protection of constitutional democracy. The committee remarks that freedom of expression sits with human dignity and equality at the heart of a value system underlying the Constitution. The Constitutional Court, meanwhile, has held that it is an essential foundation for a democratic society. ${ }^{43}$

Specific components of the right to freedom of expression include freedom of the press and of other media, as well as the right to receive and impart information and ideas. 44

The Constitutional Court has previously identified the importance of the media and has gone so far as to claim that the media has a duty to act with 'vigour, courage, integrity and responsibility'. 45

See eg MISA's reaction to former City Press editor Vusi Mona's testimony before the Hefer Commission of Inquiry "Disgraced" editor an embarrassment to journalism'. http://www.za.misa.org/pdf_mediabrief/vol1_15.pdf (Accessed 10 September 2007). On the opposite side of the spectrum, the legal pressure brought to bear to compel witnesses to reveal sources at the same commission is evident from Munusamy v Hefer NO 20045 SA $112(0)$.

39 Sec 14(d) of the Constitution.

40 See eg the discussion in I Currie et al Bill of Rights handbook (2005) 332-335.

41 JV Thill \& L Bovée Excellence in business communication (2001) 11.

42200311 BCLR 1283 (SAHRC).

43 Islamic Unity Convention v Independent Broadcasting Authority 20024 SA 294 (CC) 27.

44 Secs 16(1)(a) \& 16(1)(b) of the Constitution.

45 Khumalo (n 36 above) para 24. 
International courts have held that for the media to be free, protection of sources is one of the fundamental conditions required. 46 Or, as Currie and de Waal have it, the press can neither live freely nor operate effectively if they live "under the shadow of legal compulsion to reveal its sources of information'. 47 The conclusion is clear - any forced disclosure violates section 16(1)(a).

The right to receive and impart information was extensively canvassed by the Constitutional Court in Case $v$ Minister of Safety and Security. ${ }^{48}$ In her judgment, Mokgoro $J$ quotes from Stanley $v$ Georgia, ${ }^{49}$ where the US Supreme Court was of the view that the right to receive information and ideas was fundamental to a free society. As has been noted above, the compulsory disclosure of journalistic sources has been found to have a chilling effect on the media. Sources are more reluctant to come forward where there is a chance that their involvement may be made public. This then directly impacts upon the media's right to receive information in the most drastic way possible - it cuts such information flows off.

The European Court of Human Rights has recognised a duty on the press to impart information for the media to play its 'vital role of public watchdog'. 50 Thus, as an agent of democracy, the press has an undeniable interest in the free-flow of such information. To frustrate it - even possibly - clearly is a violation of the constitutional protection granted in terms of section 16(1)(b).

Both of these sections are knocked over by the working of section 189. The press is not free when it has to consider constantly whether the publication of a story will lead to a journalist possibly being detained for simply knowing something and refusing to compromise the ethical foundations of his profession. Likewise, there can be no doubt that the right to impart and receive information is violated where there is a shut off of the flow of such information.

Having established that, in its current form, section 189 violates at least two fundamental rights, the question to be asked is that which was highlighted by Ackerman J in Nel: What impact does section 36 of the Constitution bring to bear on the situation? Section 36 regulates

Goodwin (n 35 above) 39.

Currie et al (n 39 above) 366.

Case $v$ Minister of Safety and Security 19963 SA 617 (CC).

Stanley v Georgia 1969399557 (US) 564.

Jelsild v Denmark 199519 EHRR 1. 
society in that it holds no right absolute, no interest beyond the law. ${ }^{51}$ In terms of section 36, any right contained in the Bill of Rights may be limited if the limitation is 'reasonable and justifiable in an open and democratic society, based on equality and freedom' and taking into account all relevant factors.

For there to be a limitation of a right, there must be a law of general application. Whilst this particular phrase has a very particular, if well-hidden, meaning, ${ }^{52}$ it seems clear that section 189 , as part of a duly enacted legislative scheme, passes muster. ${ }^{53}$ Passing this hurdle opens Pandora's box, so to speak, and begins the process of evaluating the rights.

Section 36 lists five factors which should be taken into consideration in determining whether a limitation is reasonable and justifiable. ${ }^{54}$ These are the nature of the right, the importance of the purpose of the limitation, the nature and extent of the limitation, the relationship between the limitation and its purpose, and any less restrictive means of achieving the purpose.

The purpose behind section 189 - and the section 205 procedure has an undeniably important objective: it is designed to ensure the free flow of relevant information during a trial. This is coupled with the protection of a fundamental right - section 35(3)(i) of the Constitution provides all accused persons with the right to adduce and challenge evidence. Having no procedure to ensure that witnesses provide evidence renders such a right rather bald. Many people would, if possible, prefer not to testify.

51 S Woolman \& $\mathrm{H}$ Botha 'Limitations' in S Woolman et al Constitutional law of South Africa (2006) 34-1, except of course where a limitation fails to comply with the dictates of sec 36 and the factors that it demands receive attention by a court.

52 Woolman \& Botha (n 50 above) 34-47 et seq.

53 So as not to gloss over the point, Woolman and Botha identify four criteria which have to be met for a law to be a law of general application. These are that the law must ensure parity of treatment, there must be a discernable standard (ie that the law must not be arbitrary), the law must be precise enough to tailor individual conduct to it and that the law must be accessible. It is submitted that sec 189 does comply with such. In Dawood v Minister of Home Affairs 20003 SA 936 (CC) para 47, the court identified that the concept of the rule of law demanded that rules be accessible and clear. This, according to Currie et al (n 40 above) 169 , means that people should be able to tailor their conduct to meet the demands of the law. Moreover, the law should apply impersonally and equally to all.

54 It must be noted that, in this respect, the language of sec 36 is very clear. By use of the word 'including', the five factors presented in sec 36 cannot be said to represent a numerus clausus. This would, therefore, allow a court to add additional factors should it see the need. 
But it is the contextualised situation which is the relevant one. Excluding for the present the issues of detention without trial, opaquely addressed by the Court in $\mathrm{Nel}$, and the wider constitutional position of section $189,{ }^{55}$ the reality is that under certain circumstances the law allows - no, demands - that persons with relevant admissible evidence do not disclose it. The rationale behind legal practitioners' privilege, alluded to above by Lord Taylor, is that the public interest which is at stake far exceeds the interest which may be infringed by disallowing such evidence. Likewise, it is legally recognised that spouses are generally incompetent to testify against one another. To propose that the vital interests which a media privilege would protect are any less important would fly in the face of the jurisprudence of the Constitutional Court in recognising the need for a free-flow of information and expression. ${ }^{56}$

There is at stake a wider societal interest. It has been mentioned above that the forced disclosure of a journalist's sources has a chilling effect on the media. To chill the media denies it the freedom granted in terms of section 16(1)(a) of the Constitution. It removes the very freedom which the press is notionally supplied with. It deprives it of the opportunity of exercising its constitutionally demanded role of promoting the free flow of information, ${ }^{57}$ without living under the constant shadow of possible detention.

The Supreme Court of Appeal in Bogoshi ${ }^{58}$ was quick to remove the burden of strict liability for publishing falsehoods that had been imposed on the press in the Pakendorf case. ${ }^{59}$ Its reasoning was based precisely on the chilling effect that such potential liability imposed on the media. ${ }^{60}$ There is therefore clear support for the notion that the media should be 'unchilled'. Likewise, the same argument has to apply to other indirect restraints such as section 189 .

The current breakdown in institutions supporting democracy, parliament's constant deferral to the executive as well as the opaque decision-making process of the ruling party, have left the press as the

The view of Kriegler J in S v Mamabolo 20013 SA 409 (CC) as to the desirability of such summary procedures is directly relevant. Here the court held that such procedures are generally undesirable, especially as courts are the guardians of constitutional rights. They should be reserved for the most exceptional cases, according to Kriegler $\mathrm{J}$.

56 The court's dictum in Khumalo (n 36 above) para 24 is evidence of such.

$57 \quad$ Khumalo (n 36 above) para 24.

58 National Media v Bogoshi 19984 SA 1196 (SCA); 19984 All SA 357 (A).

59 Pakendorf $v$ De Flamingh 19823 SA $146(\mathrm{~A})$

60 Per Hefer JA 359 (All SA). 
most important agent supporting democracy. ${ }^{61}$ This is a task which goes to the heart of an open and democratic society - it is its very lifeblood. ${ }^{62}$

The right to freedom of expression has been exalted by the Constitutional Court. In Mamabolo, Kriegler $\mathrm{J}$ held that it was of utmost importance to the open and democratic society to which we aspire. ${ }^{63}$ Likewise, O'Regan J in South African National Defence Union $v$ Minister of Defence, ${ }^{64}$ recognised that freedom of expression is the guarantor of democracy. It is therefore submitted that interests protected by section 189 should be subordinate to the rights infringed.

There is yet another facet to this argument. The right to dignity is, constitutionally, both a distinct right and a foundational value. ${ }^{65}$ Journalistic ethics militate strongly against any form of source disclosure, precisely because this undermines the integrity of the profession as a whole. ${ }^{66}$ Dignity, the Court in Dawood was quick to point out, ${ }^{67}$ seeks to foster respect for the intrinsic worth of all human beings. But not only other human beings - in Williams, the Court struck down provisions of the Criminal Procedure Act because of the deprivation of the dignity of the person of the offender. ${ }^{68}$ Section 189 imposes what may be described in context of judicial decision-making as a hard choice on a journalist who is asked on the stand to reveal sources. He is forced to confront breaking an ethical rule of his profession or being incarcerated. He is also forced to choose whether to betray the trust that his source placed in him. Although perhaps not the most serious violation of dignity that has ever occurred, it is still a violation. It goes directly to his self-respect, his integrity.

61 See eg events leading up to the Hefer Commission of Inquiry; Tshabala-Msimang $v$ Mahkanya (unreported WLD decision of 30 August 2007, per Jajbhay J); SABC exposé regarding the suspension of NDPP Vusi Pikoli and an arrest warrant for National Police Commissioner Jackie Selebi. All of these events have exposed political wrangling at the highest level and have shed light on matters which otherwise would not, I believe, have been granted the oversight required in a democracy based on human dignity, equality and freedom. In Jelsild (n 49 above) 35, the European Court held that news reporting constitutes one of the most important means for the press to play its role as public watchdog.

63 Mamabolo (n 54 above) para 37.

6419994 SA 469 (CC).

65 Sec 11 embraces the right, amongst others, sec 2 the value.

66 See eg $n 39$ above.

67 n 52 above, para 35.

$68 S \vee$ Williams 19957 BLCR 861 (CC). The relevant sections allowed for corporal punishment of convicted persons. 
The link between the need for information and the violation of the rights is perhaps fairly clear. However, section 189 is not necessarily effective at ensuring that a witness testifies. ${ }^{69} \mathrm{~A}$ witness could choose to remain silent indefinitely. Thus, the purpose for the violation is frustrated. Likewise, especially in the context of section 205, the current violation is not the most narrowly tailored way of obtaining the information.

An accessory after the fact in a criminal context can be someone who impedes the course of justice after a crime has been committed. ${ }^{70}$ Thus, a journalist who is questioned by a policeman about the identity of a supposed criminal and who fails to disclose this could, in principle, be criminally liable as an accessory to the crime. This may, at first glance, seem draconian. But at least this would ensure that a journalist from whom information is sought is clothed with the rights of an accused person, and not the summary procedures endorsed in $\mathrm{Nel}$ and doubted in Mamabolo. It would also require that the state prove all five elements of criminal liability beyond reasonable doubt. This includes unlawfulness. It therefore grants a journalist who knows the identity of a criminal far greater protection, whilst being constitutionally acceptable.

It is therefore submitted that in its current form and general application, section 189 is not a reasonable and justifiable limitation of the rights of freedom of expression and privacy. Obviously, and given the flexibility suggested in $\mathrm{Nel}$, under certain circumstances the societal interest in the disclosure of information would exceed the prejudice caused. However, in such cases, it is submitted that the person seeking such disclosure must bear the onus of proving that the limitation is reasonable and justifiable. Furthermore, such situations should be very clearly the exception with regard to journalists.

\section{8}

\section{Summary}

Despite massive doubts about the actual constitutionality of section 189 , which were in no way allayed by the decision of the Constitutional Court in Nel $v$ Le Roux, the decision perhaps has an effect thus far unrecognised. Ackerman J's finding that a witness is under no obligation to answer a question which infringes, or threatens to infringe, any fundamental right in a manner not saveable under section 36, does indeed establish a journalistic privilege. This privilege is flexible enough to prevent a total frustration of the aims of section 189 in so-called 'ticking bomb' cases.

The forced disclosure of journalistic sources is a violation of the right to privacy and freedom of expression. To adopt the Nel approach 
to section 189 holds nothing less than the realisation of such a privilege - and at the same time perhaps even saves section 189 from being struck down, a fate alluded to by Ackerman $\mathrm{J}$ in $\mathrm{Nel} .^{71}$

71 Sec 189 was not the actual subject of $\mathrm{Nel}$ (n 21 above) - rather its inclusion in sec 205. Ackerman J seems to suggest that had sec 189 itself been referred, the decision of the court may have been different ( $\mathrm{Nel}$ (n 21 above) para 26). 